\title{
Mapping Recent Developments in Transparency of Extractive Industries
}

\author{
Zorka MILIN*
}

Keywords: extractive industries, natural resources, transparency

\section{INTRODUCTION}

Secrecy and poor human rights often go hand in hand with each other, especially in developing countries that are rich in natural resources. This is part of the phenomenon known as the "resource curse"- the paradox that many resource-rich countries tend to be even worse off than otherwise similarly situated countries: more impoverished, more unequal, more authoritarian and more conflict-prone. ${ }^{1}$

In an effort to alleviate the resource curse, a number of transparency initiatives and laws have emerged in recent years, seeking to ensure that natural resource wealth will benefit the people of resource-rich developing countries, rather than perpetuate corruption, conflict and poverty. This includes a variety of legal mandates and quasi-voluntary commitments to: disclose revenues paid by companies to resource-rich countries; fully disclose terms of natural resource contracts; report on the presence of conflict minerals in corporate supply chains; and make public who benefits from anonymous companies that are involved in natural resource extraction. ${ }^{2}$ Covering all of these issues is beyond the scope of this piece. The aim here is to survey and map this landscape, with a particular focus on revenue transparency, and with an eye to outlining the emerging global transparency standard and reflecting on some challenges that lie ahead and the broader significance of natural resource revenue transparency, in particular linkages with human rights issues.

* Senior Legal Advisor at Global Witness. This article reflects the personal views of the author and does not necessarily represent the views of Global Witness.

1 Academics and activists have documented the correlations between the resource curse and global poverty. See, for example, Michael Ross, Extractive Sectors and the Poor (Oxfam America: 2001).

2 On contract transparency, see generally, http://www.open-contracting.org/extractives (accessed 10 February 2016); Peter Rosenblum and Susan Maples, Contracts Confidential: Ending Secret Deals in the Extractive Industries (2009), http://www.resourcegovernance.org/publications/contracts-confidential-ending-secret-deals-extractive-industries (accessed 10 February 2016). On conflict minerals, see International Peace Information Service, Mineral Supply Chain and Conflict Links in Eastern Democratic Republic of Congo, (2015), http://mneguidelines.oecd.org/mineral-supplychain-eastern-drc.htm (accessed 10 February 2016). 


\section{BACKGROUND}

The global movement for extractives revenue transparency has its origins in the late 1990s. It was spurred on by the pioneering investigations by the international organization Global Witness exposing how the secrecy over oil revenues in Angola facilitated corruption and prolonged a civil war there. Following its 1999 report A Crude Awakening, Global Witness issued another report in 2002, All the Presidents' Men, which concluded with a public call on the oil companies operating in Angola to 'Publish What You Pay!' ${ }^{3}$ Under this rallying call, a group of London-based activists, including Global Witness, Save the Children, Transparency International, Catholic Agency For Overseas Development (CAFOD), Open Society Institute, Oxfam, and others, came together to launch the Publish What You Pay (PWYP) campaign in mid-2002. ${ }^{4}$ Today, PWYP is a diverse international coalition of over 800 civil society organizations, including human rights, development, environmental and faith-based groups in over 60 countries, all of them united around ensuring that natural resources are used for public benefit. $^{5}$ Over the course of ten years, PWYP has been remarkably effective in accomplishing its campaign objectives, both at the international and domestic levels, as discussed in Parts III and IV below.

\section{Quasi-voluntary International Regime}

The launch of PWYP in 2002 was followed by the launch of the Extractives Industry Transparency Initiative (EITI) in 2003, the major international initiative in this area, with 49 countries taking part as of this writing. EITI is often described as a voluntary scheme, and this is true, but only in the sense that it is voluntary for countries to sign up. Once a country is a member, it is mandatory for extractive companies operating inside that country to declare what they pay to the government, and conversely, the government must declare what it receives from companies, so that payments and receipts can be matched. Many EITI member countries convert their international EITI commitments into binding national laws by enacting legislation that implements the EITI requirements.

One of the innovative aspects of EITI is a new form of collective international governance that is not limited to governments alone, but also ensures participation from industry and civil society on an equal footing via its tripartite stakeholder governance structure. ${ }^{6}$ Nevertheless, the crucial decision of joining the EITI can only be made by a country's government, which means that EITI does not reach some of the most secretive and corrupt governments that are in greatest need of transparency. This is one major limitation of EITI, and it points to the need for mandatory legal mechanisms (discussed

\footnotetext{
3 Global Witness, A Crude Awakening: The Role of the Oil and Banking Industries in Angola's Civil War and the Plunder of State Assets (December 1999), http://www.globalwitness.org/library/crude-awakening (accessed 10 February 2016); and Global Witness, All the Presidents' Men (March 2002), http://www.globalwitness.org/library/ all-presidents-men (accessed 10 February 2016).

4 Mabel van Oranje and Henry Parham, Publishing What We Learned: An Assessment of the Publish What You Pay Coalition (2009), at 31-5, http://www.publishwhatyoupay.org/resources/publishing-what-we-learned (accessed 10 February 2016).

5 http://www.publishwhatyoupay.org/about (accessed 10 February 2016).

6 See Eddie Rich and Jonas Moberg, Beyond Governments - Making Collective Governance Work: Lessons from the Extractive Industries Transparency Initiative (Sheffield: Greenleaf Publishing, 2015).
} 
in Part IV below). Importantly, these two approaches are complementary, as was recognized at the international level in 2013, when the G8 leaders agreed at the Lough Erne summit to raise global standards for extractives transparency both for host countries (via EITI) and for home countries of large multinational extractives corporations (via mandatory legal measures). ${ }^{7}$ Some G8 countries, including the US and the UK, have also opted to join EITI themselves, reaffirming their leadership on global extractives transparency.

\section{Laws Mandating Revenue Disclosure}

In 2010, the United States became the first country to mandate that extractive companies make public their payments to governments around the world. This ground-breaking provision was enacted as part of the Dodd-Frank Wall Street Reform and Consumer Protection Act, and is known as Section 1504. ${ }^{8}$ In 2012, it was set to be implemented through a rule issued by the US financial regulatory agency, Securities and Exchange Commission (SEC) (hereafter, the 2012 SEC rule). ${ }^{9}$ However, implementation was delayed after the SEC rule was set aside in a 2013 court decision as a result of a legal challenge by the US oil industry association American Petroleum Institute (API). ${ }^{10}$ API persuaded a judge that the 2012 SEC rule did not adequately take into account the costs to industry of making disclosures that are allegedly commercially sensitive. API would like for these disclosures to be anonymized and aggregated so that payments are linked neither to individual companies nor to specific contracts and projects, and moreover, to be exempt from reporting payments made to certain countries that have secrecy laws allegedly in conflict with Section 1504. ${ }^{11}$ Transparency advocates insist that this would defeat the central purpose of the law to produce information that can empower activists, journalists and investors to hold to account governments and companies for how natural resource payments are managed.

Due to the legal setback, the SEC has had to go back to the drawing board and is currently rewriting the rule. It is important to note that the court decision does not require the SEC to alter the 2012 rule, but only to revisit its justifications supporting the rule, in particular the cost-benefit analysis. In December 2015, the SEC issued a strong proposal, currently subject to public consultation and scheduled to be finalized by mid-2016. While the US implementation has been stalled, other jurisdictions have followed the US example and enacted their own versions of similar legal mandates.

Europe. In 2013, the European Union (EU) adopted new laws requiring annual disclosure of payments made by extractive and forestry companies that are registered in the EU as well as those that issue securities on regulated markets in the EU. ${ }^{12}$ The EU

\footnotetext{
7 Lough Erne Communique, para 36, 9 (18 June 2013), https://www.gov.uk/government/uploads/system/uploads/ attachment_data/file/207771/Lough_Erne_2013_G8_Leaders_Communique.pdf (accessed 10 February 2016).

8 U.S.C. $78(q)$.

977 Fed. Reg. 56365.

10 American Petroleum Institute v SEC, 953 F.Supp.2d 5 (D.D.C. 2013).

11 Zorka Milin and Barnaby Pace, 'Slick Moves', Foreign Policy (7 March 2014), http:/foreignpolicy.com/2014/03/ 07/slick-moves (accessed 10 February 2016).

12 These requirements form Chapter 10 of the EU Accounting Directive (adopted on 26 June 2013) and art 6 of the revised EU Transparency Directive (adopted on 17 October 2013). See Miles Litvinoff, Achieving Extractive
} 
requirements were inspired by and modelled on the 2012 SEC rule. They have already been transposed into domestic laws of the United Kingdom and other key EU member states, and first reports are due this year.

In addition, Norway has also passed its own legislation in December 2013 introducing reporting for Norwegian extractive companies which came into effect on 1 January 2014. First reports were made in 2015, including by the oil giant Statoil, the first major oil company in the world to disclose its payments to governments. ${ }^{13}$ Significantly, Statoil has suffered no negative repercussions from making these disclosures, which undermines US oil industry speculations that payment information is commercially sensitive and that its disclosure would cause competitive disadvantage.

Canada. In December 2014, the government of Canada adopted the Extractive Sector Transparency Measures Act (ESTMA), which came into force on 1 June 2015. ${ }^{14}$ Canadian law and relevant implementation tools are broadly consistent with the EU Directives and the 2012 SEC rule. Unique to Canada, civil society and the mining industry joined forces to form the Resource Revenue Transparency Working Group (RRTWG) which has played an instrumental role in shaping the Canadian transparency law. ${ }^{15}$ The legal developments in Canada are of particular global significance because they will apply to a majority of public mining companies in the world, 57 per cent of which are listed on the Toronto Stock Exchange. ${ }^{16}$

Other jurisdictions. In addition to the three established markets discussed above, some emerging markets have also begun to adopt similar transparency rules. The Hong Kong Stock Exchange has adopted new listing rules mandating disclosure of payments by newly-listed extractive companies to host country governments in respect of tax, royalties and other significant payments, effective 3 June $2010 .{ }^{17}$ Such payments are required to be disaggregated on a country basis, but not necessarily by project. Unlike the laws in the US, Europe and Canada, all of which require ongoing annual reporting, the Hong Kong rules apply upon new issuer listing and upon major acquisitions of mineral or petroleum assets.

In South Africa, the minister of mineral resources has recently expressed support for transparency requirements for oil, gas and mining companies that are listed on the Johannesburg Stock Exchange. ${ }^{18}$ These are hopeful signals: capturing companies from emerging markets is important given their increasing prominence in the global extractives sector.

\footnotetext{
(F'note continued)

Transparency in the European Union (June 2015), http://www.publishwhatyoupay.org/wp-content/uploads/2015/07/ EU_Case_study.pdf (accessed 10 February 2016).

13 http://www.statoil.com/no/InvestorCentre/AnnualReport/AnnualReport2014/Documents/DownloadCentreFiles/

01_KeyDownloads/2014\%20Payments\%20to\%20governments.pdf (accessed 10 February 2016).

14 http://laws-lois.justice.gc.ca/PDF/E-22.7.pdf (accessed 10 February 2016).

15 http://www.pwyp.ca/en/work-areas/mandatory-disclosure/transparency-working-group (accessed 10 February 2016).

16 http://mining.ca/resources/mining-facts (accessed 10 February 2016).

17 Rules Governing the List of Securities on the Stock Exchange of Hong Kong Limited, Chapter 18, http://www. hkex.com.hk/eng/rulesreg/listrules/mbrules/documents/chapter_18.pdf (accessed 10 February 2016).

18 Remarks made by Ngoako Ramatlhodi at Extractive Industries in Africa: New Approaches to Overcome Enduring Challenges, event in Chatham House, London (16 March 2015).
} 


\section{Conclusion: Challenges Ahead and Broader Significance}

Recent years have seen great global momentum towards a more transparent extractive industries sector, with transparency initiatives and laws covering 49 resource-rich countries as well as over 70 per cent of major public oil, gas and mining companies, but there remain some challenges. First, there is a risk that a strong US rule on transparency could be subject to further legal challenges by the oil industry, which could cause additional implementation delays. A second challenge is to develop consistency across different national and international standards: this is essential to ensure that the data produced pursuant to different reporting regimes is easily comparable from the perspective of public users, including anticorruption activists, journalists and investors. From the perspective of companies, consistency is critical in order to minimize compliance costs for those companies that are subject to multiple reporting standards. Fortunately, the EITI standard explicitly provides that revenues must be broken down by each individual project, consistent with both EU and US law. ${ }^{19}$ This creates strong incentives for the US regulators to ensure that their final rule is consistent with the rules already in place in Europe, to avoid creating confusion and discrepancy between different transparency regimes.

The initial motivations for lifting the veil on extractives industries were primarily centred around alleviating conflict and corruption in developing countries, but it has become apparent that transparency regarding natural resource revenues also has the potential to advance other important advocacy and policy interests, such as respecting the right to free, prior and informed consent, tackling climate change and addressing tax abuses.

First, in too many resource-rich developing countries, natural resource extraction takes place without the full free, prior, and informed consent of affected communities. ${ }^{20}$ To ensure that this consent is fully informed, communities should have access to adequate information about the costs and benefits to them of proposed extraction projects, including expected revenues as well as environmental consequences.

Second, revealing the payments that companies actually make to governments raises questions about why such payments can turn out below expectations, depriving developing country governments of funding they need to fulfil important social and economic rights such as health and education. ${ }^{21}$ This can happen as a result of corporate tax abuse, which is enabled by tax secrecy. Tax justice groups have been advocating for a requirement that all multinational companies disclose the taxes they pay in each country. Extractives sector tax transparency provides an important precedent for other industries. $^{22}$

19 EITI Standard 5.2(e), https://eiti.org/files/English_EITI\%20STANDARD_11July_0.pdf (accessed 10 February 2016).

20 FPIC is an internationally recognized human right with respect to indigenous peoples. United Nations Declaration on the Rights of Indigenous Peoples (2007), art 10.

21 See generally, International Bar Association Human Rights Institute, Tax Abuses, Poverty and Human Rights, (23 October 2013), http://www.ibanet.org/Human_Rights_Institute/TaskForce_IllicitFinancialFlows_Poverty_HumanRights. aspx (accessed 10 February 2016).

22 Corinna Gilfillan, 'Country-by-Country Reporting and the Global Standard of Extractive Industry Transparency', (2014) 9 Tax Justice Focus 8, http://www.taxjustice.net/wp-content/uploads/2013/04/TJF-2014-Country-by-Country. pdf (accessed 10 February 2016). See also Zorka Milin, 'Global Tax Justice and the Resource Curse: What Do Corporations Owe?' (2014) 1 Moral Philosophy and Politics 17. 
Third, extractives industries transparency can contribute to addressing one of the greatest human rights challenges of our time: climate change. Making public the actual payments that extractive companies make to governments can highlight the relative enormity of revenues that are foregone as a result of fossil fuel subsidies. While the transparency regimes outlined above are focused on revenues and do not cover subsidies, there is no reason that subsidies cannot be incorporated into the transparency regimes. For example, the magnitude of tax breaks enjoyed by the US extractives sector has been highlighted in the recently published first US EITI report. ${ }^{23}$ Making such information public can help to educate the public and inform policy around fossil fuel extraction.

Throwing open the curtains on the secrecy that has surrounded natural resource payments to governments for too long will have a transformative impact in resource-rich countries around the world and across many areas of social justice, from mitigating corruption, conflict and poverty to helping to address some of the most pressing global injustices.

23 US EITI, 'Tax Expenditures', 2015 Executive Summary, 48. See also https://useiti.doi.gov/how-it-works/revenues/ tax-expenditures (accessed 10 February 2016). 